\title{
Differential impact of two doses of antithymocyte globulin conditioning on lymphocyte recovery upon haploidentical hematopoietic stem cell transplantation
}

Jiangying Liu, Lan-Ping Xu, Zhilei Bian, Ying-Jun Chang, Yu Wang, Xiao-Hui Zhang and Xiao-Jun Huang*

\begin{abstract}
Background: In vivo depletion of host T cells with antithymocyte globulin (ATG) is a common strategy for preventing graft-versus-host disease in allogeneic hematopoietic stem cell transplantation (HSCT). The total dose of ATG in conditioning regimens appears to be an important factor that influences the outcome in recipients of transplants. However, the optimal ATG dosage has not been established to date. It remains unclear whether, in the setting of haploidentical HSCT (haploHSCT), different doses of ATG might exert differential influences on the recovery of lymphocyte subpopulations.
\end{abstract}

Methods: This retrospective study analyzed lymphocyte recovery and its correlation to viral infection in two groups of patients that received different doses of ATG before haploHSCT. We performed flowcytometry to determine immunophenotypes of $\mathrm{CD} 19^{+} \mathrm{B}$ cells and $\mathrm{CD}_{3}^{+}, \mathrm{CD}^{+}, \mathrm{CD}^{+}, \mathrm{CD}^{+}{ }^{+} \mathrm{CD} 45 \mathrm{RA}^{+}, \mathrm{CD}^{+}{ }^{+} \mathrm{CD} 45 \mathrm{RO}^{+}, \mathrm{CD}^{+}{ }^{+} \mathrm{CD} 28^{+}, \mathrm{CD} 8^{+} \mathrm{CD} 28^{+}$, and $\mathrm{CD} 4^{-} \mathrm{CD} 8^{-} \mathrm{T}$ cells.

Results: We found that, compared to $6 \mathrm{mg} / \mathrm{kg}, 10 \mathrm{mg} / \mathrm{kg}$ ATG significantly hampered the recoveries of CD4 ${ }^{+}$, $\mathrm{CD}^{+}{ }^{+} \mathrm{CD} 45 \mathrm{RA}^{+}$, and $\mathrm{CD} 4^{+} \mathrm{CD} 45 \mathrm{RO}^{+} \mathrm{T}$ cells in the first 2 months following haploHSCT. Similarly, compared to $6 \mathrm{mg} / \mathrm{kg}$, the $10 \mathrm{mg} / \mathrm{kg}$ dose of ATG negatively influenced the recoveries of $\mathrm{CD} 4^{-} \mathrm{CD} 8^{-}$and $\mathrm{CD} 8^{+} \mathrm{CD} 28^{+} \mathrm{T}$ cells; recovery was delayed for 6 and 12 months after transplantation, respectively. Moreover, we showed that an increase in Epstein-Barr virus (EBV) infections, associated with the higher dose of ATG, was correlated with the delayed recovery of $C D 4^{-} \mathrm{CD}^{-}$ double negative T cells.

Conclusions: The present study revealed a differential impact of different ATG conditioning doses on the recoveries of T cell subpopulations post-haploHSCT. This study was the first to connect the recovery of $C D 4^{-} \mathrm{CD} 8^{-} \mathrm{T}$ cells to the risk of EBV infection after HSCT. These findings will facilitate optimization of the ATG conditioning dosage and improve the outcome of patients with leukemia that receive haploHSCT.

Keywords: Hematopoietic stem cell transplantation, Antithymocyte globulin (ATG), Immune reconstitution, Viral infection, Epstein-Barr virus (EBV)

\section{Background}

Haploidentical hematopoietic stem cell transplantation (haploHSCT) constitutes an important alternative for

\footnotetext{
*Correspondence: huangxiaojun@bjmu.edu.cn

Peking University People's Hospital, Peking University Institute

of Hematology, Beijing Key laboratory of Hematopoietic Stem Cell

Transplantation, 11 Xizhimen South Street, Beijing 100044, China
}

patients with leukemia that lack a donor with matching human leukocyte antigen (HLA). However, graft-versus-host disease (GVHD) is a frequent, life-threatening complication of haploHSCT. To prevent GVHD, patients often receive antithymocyte globulin (ATG), a polyclonal immunoglobulin preparation obtained by immunizing rabbits or horses with human thymocytes or T cell lines. This strategy of in vivo $\mathrm{T}$ cell depletion with ATG has 
been quite successful in preventing the development of both acute and chronic GVHD after hematopoietic stem cell transplantation (HSCT) from HLA-matched, unrelated donors [1-3]. Studies from our group and others have suggested that ATG can also overcome the negative influence of HLA-mismatched HSCT [4-7].

However, the virtual depletion of $\mathrm{T}$ cells increases both the risk of developing a severe infection and the risk of a malignancy relapse after HSCT. Therefore, it has become critical to determine a suitable dose of ATG in conditioning regimens [8]. Although the total dose of ATG appears to have an important influence on the overall clinical outcome of transplantation, studies on the impact of different ATG doses have produced inconsistence [9-11], and an optimal dose has not been established.

It has been recognized that viral infections and other complications of HSCT are closely associated with the reconstitution of the immune system. A growing number of studies have demonstrated the negative impact of ATG on the recovery of lymphocytes after transplantation [12-14]. In the haploHSCT setting, our previous prospective study reported that, compared to $6 \mathrm{mg} / \mathrm{kg}$ ATG, $10 \mathrm{mg} / \mathrm{kg}$ ATG conditioning regimen increased the risk of EBV infection, but reduced the incidence of grades III-IV acute GVHD [15]. Although patients that received higher ATG dose showed delayed recoveries of $\mathrm{CD} 19^{+} \mathrm{B}$ cells, $\mathrm{CD}^{+}{ }^{+} \mathrm{T}$ cells, and $\mathrm{CD} 4^{+} \mathrm{T}$ cells 30 days after transplantation, it was not clear whether lymphocyte recovery at later stages and the recoveries of differential $\mathrm{T}$ cell subpopulations were affected by different doses of ATG. Moreover, the cause-consequence relationship between immunodeficiency and the occurrence of viral infections was not demonstrated in this context.

In the present study, we extended the comparison between the two different ATG-conditioning doses in the context of haploHSCT to include more lymphocyte subpopulations and longer follow-up times. Thus, in addition to $\mathrm{CD} 19^{+} \mathrm{B}$ cells and $\mathrm{CD}^{+}$and $\mathrm{CD} 4^{+} \mathrm{T}$ cells, we studied recoveries of $\mathrm{CD}^{+}, \mathrm{CD}^{+}{ }^{+} \mathrm{CD} 45 \mathrm{RA}^{+}, \mathrm{CD}^{+} \mathrm{CD} 45 \mathrm{RO}^{+}$, $\mathrm{CD} 4^{+} \mathrm{CD} 28^{+}, \mathrm{CD}^{+}{ }^{+} \mathrm{CD} 28^{+}$, and $\mathrm{CD} 4^{-} \mathrm{CD} 8^{-} \mathrm{T}$ cells for an extended time course (12 months after transplantation). Our results showed hampered recovery of some $\mathrm{T}$ cell subsets and a correlation between the delayed recovery and increased risk of EBV infection with $10 \mathrm{mg} / \mathrm{kg}$ ATG treatment. These results emphasized the need to optimize the ATG dosage in conditioning regimens to facilitate recovery of the immune system and improve the outcome for recipients of haploHSCT.

\section{Methods}

\section{Patients and study design}

The aim of this study was to compare lymphocyte recovery and its correlation to viral infections between patients that received two different doses of ATG as conditioning for haploHSCT. We retrospectively screened participants from an open-label, prospective, randomized trial (No. ChiCTR-TRC-11001761), which included 224 patients randomly assigned to receive either $6 \mathrm{mg} / \mathrm{kg}$ or $10 \mathrm{mg} / \mathrm{kg}$ ATG [15]. All subjects were diagnosed with standard-risk hematological malignancies and underwent haploHSCT in our institute from December 2010 to May 2012. The Ethics Committee of Peking University Institute of Hematology approved the study protocol. All recipients and their donors signed consent forms. Because immune reconstitution was neither the primary nor the secondary end point in that prospective study, only 60 subjects had been monitored for lymphocyte recovery at serial time points $(30,60,90,180$, and 360 days post-transplantation). Therefore, these 60 subjects were recruited for the current study.

Patients were conditioned with intensive chemotherapy-based regimens (mainly busulfan, cyclophosphamide, and ATG), as described in detail previously [15]. ATG (thymoglobulin; rabbit ATG, Imtix Sangstat, Lyon, France) doses were administered from day -5 to day -2 before transplantation. Patients that received $6 \mathrm{mg} /$ kg ATG (ATG-6 group) were administrated $1.5 \mathrm{mg} / \mathrm{kg}$ per day; patients that received $10 \mathrm{mg} / \mathrm{kg}$ ATG (ATG10 group) were administrated $2.5 \mathrm{mg} / \mathrm{kg}$ per day. The transplant procedures, GVHD prophylaxis (including cyclosporine $\mathrm{A}$ and short-term methotrexate with mycophenolate mofetil) and treatment, and evaluations of acute GVHD and viral infections/reactivations were described previously [15].

\section{Immunophenotyping analysis}

Immunophenotyping for $\mathrm{B}$ and $\mathrm{T}$ lymphocytes was performed with flowcytometry post-haploHSCT. Briefly, fresh peripheral blood cells were stained with fluorochrome-labeled monoclonal antibodies against cluster of differentiation (CD) cell surface molecules, CD19, CD3, CD4, CD8, CD45RO, CD45RA, and CD28 (Beckton Dickinson, San Jose, CA, USA). Polychromatic flow cytometric analyses were performed with a custom 7-laser high resolution LSRII cell analyzer (Beckton Dickinson).

\section{Statistical analysis}

Statistical differences between groups in age, incidences of acute GVHD and viral infections, and recoveries of lymphocyte subpopulations at different time points were analyzed with the Mann-Whitney U test. Statistical differences between the two groups in gender and type of primary disease were analyzed with the Chi squared test. Bivariate correlations between the recoveries of $\mathrm{T}$ cell subpopulations and the incidence of EBV infection were analyzed with the Spearman test. Statistical significance 
was defined as $P \leq 0.05$, based on a two-tailed test. All calculations were carried out with SPSS 16.0 statistical software (SPSS Inc, Chicago, IL, USA).

\section{Results}

\section{Characteristics of patients}

The characteristics of patients in the two different ATG groups are summarized in Table 1. Previous studies suggested that the age of recipients and the numbers of $\mathrm{CD} 34^{+}$cells in grafts could influence immune recovery. In the present study, there were no statistical differences in age or the numbers of CD34 $4^{+}$cells in grafts between groups. Moreover, the gender ratio and types of primary disease were similar between the ATG-6 and ATG-10 groups (Table 1). In addition, all included subjects underwent the same procedures of donor priming (recombinant human granulocyte-colony stimulating factor), graft harvesting (peripheral blood progenitor cells and unmanipulated bone marrow), and GVHD prophylaxis (cyclosporine A and short-term methotrexate with mycophenolate mofetil).

\section{Recoveries of T lymphocyte subpopulations were delayed with $10 \mathrm{mg} / \mathrm{kg}$ ATG}

We first analyzed the peripheral white blood cell (WBC) and the absolute lymphocyte counts determined in routine blood tests from day 30 to 360 after haploHSCT.

Table 1 Clinical characteristic of patients

\begin{tabular}{|c|c|c|c|}
\hline & ATG-6 & ATG-10 & $P$ value \\
\hline Subjects, n & 29 & 31 & \\
\hline Age, years, median (range) & $22(16-48)$ & $29(15-48)$ & 0.11 \\
\hline \multicolumn{4}{|l|}{ Gender, n (\%) } \\
\hline Male & $18(62.1)$ & $24(77.4)$ & 0.19 \\
\hline Female & $11(37.9)$ & $7(22.6)$ & \\
\hline \multicolumn{4}{|l|}{ Diagnosis, n (\%) } \\
\hline $\mathrm{AML}$ & $12(41.4)$ & $14(45.2)$ & 0.77 \\
\hline ALL & $12(41.4)$ & $12(38.7)$ & \\
\hline $\mathrm{CML}$ & $2(6.9)$ & $3(9.6)$ & \\
\hline MDS (RAEB) & $3(10.3)$ & $2(6.5)$ & \\
\hline $\begin{array}{l}\text { CD34 }{ }^{+} \text {cells in graft, } \\
\times 10^{6} / \mathrm{kg} \text {, median (range) }\end{array}$ & $2.4(0.7-4.9)$ & $3.1(0.3-7.8)$ & 0.32 \\
\hline Donor type & \multicolumn{3}{|c|}{ Related donors } \\
\hline HLA typing & \multicolumn{3}{|c|}{ 1-3/6 Mismatch } \\
\hline Stem cell source & \multicolumn{3}{|c|}{$\mathrm{BM}+\mathrm{PB}$} \\
\hline Conditioning regimen & \multicolumn{3}{|c|}{$B U+C Y+A T G$} \\
\hline GVHD prophylaxis & \multicolumn{3}{|c|}{$\mathrm{CSA}+\mathrm{MMF}+\mathrm{MTX}$} \\
\hline
\end{tabular}

ATG antithymocyte globulin, $A M L$ acute myeloid leukemia, $A L L$ acute lymphoblastic leukemia, $B M$ bone marrow, $B U$ busulfan, $C M L$ chronic myeloid leukemia, CSA cyclosporine A, CY cyclophosphamide, HSCT hematopoietic stem cell transplantation, $M D S$ myelodysplastic syndrome, $M M F$ mycophenolate mofetil, $M T X$ methotrexate, $P B$ peripheral blood
As shown in Table 2, the median levels of total WBC and lymphocyte counts were not significantly different between the two ATG groups at the indicated time points post-transplantation. This finding indicated that the recoveries of peripheral WBCs and lymphocytes were not affected by the dose of ATG in the conditioning regimen.

Next, we compared the recoveries of B and T lymphocytes between the ATG- 6 and ATG-10 groups at serial time points and within 1 year after haploHSCT. We determined the absolute numbers of nine lymphocyte subpopulations with immunophenotyping, namely: $\mathrm{CD} 19^{+} \mathrm{B}$ cells, and $\mathrm{CD}^{+}, \mathrm{CD}^{+}, \mathrm{CD}^{+}, \mathrm{CD} 4^{+} \mathrm{CD} 45 \mathrm{RA}^{+}$, $\mathrm{CD}^{+}{ }^{+} \mathrm{CD} 45 \mathrm{RO}^{+}, \mathrm{CD} 4^{+} \mathrm{CD} 28^{+}, \mathrm{CD}^{+} \mathrm{CD} 28^{+}$, and $\mathrm{CD} 4^{-} \mathrm{CD} 8^{-} \mathrm{T}$ cells (Table 3 ). On day 30 after HSCT, the median counts of nearly all lymphocyte subsets, except $\mathrm{CD}^{+} \mathrm{T}$ cells, were significantly lower in the ATG-10 group than in the ATG-6 group. That is, the difference between groups were statistically significant $(P \leq 0.05)$ in comparing median counts of $\mathrm{CD} 4^{+}, \mathrm{CD} 4^{+} \mathrm{CD} 45 \mathrm{RA}^{+}$, $\mathrm{CD} 4^{+} \mathrm{CD} 45 \mathrm{RO}^{+}, \quad \mathrm{CD} 4^{+} \mathrm{CD} 28^{+}, \quad \mathrm{CD} 8^{+} \mathrm{CD} 28^{+}$, and $\mathrm{CD} 4^{-} \mathrm{CD} 8^{-} \mathrm{T}$ cells by the end of the first month posttransplantation; however, differences in the numbers of $\mathrm{CD} 19^{+} \mathrm{B}$ cells and $\mathrm{CD}^{+} \mathrm{T}$ cells were only close to the significance $(P=0.07$, Table 3$)$. These results demonstrated that $10 \mathrm{mg} / \mathrm{kg}$ of ATG administration, in contrast to $6 \mathrm{mg} / \mathrm{kg}$ of ATG treatment, was associated with a delayed recovery of lymphocyte subpopulations as early as the first month following haploHSCT.

The median levels of $\mathrm{CD} 4^{+}, \mathrm{CD} 4{ }^{+} \mathrm{CD} 45 \mathrm{RA}^{+}$and $\mathrm{CD} 4{ }^{+} \mathrm{CD} 45 \mathrm{RO}^{+} \mathrm{T}$ cells (representing naive and

Table 2 Peripheral white blood cells (WBC) and lymphocyte counts after ATG-conditioned haploHSCT, $10^{9} / \mathrm{L}$

\begin{tabular}{llll}
\hline & Group & WBC & Lymphocyte \\
\hline Day 30 & ATG-6 & $5.9(1.6-15.7)$ & $0.3(0.1-2.7)$ \\
& ATG-10 & $4.7(2.0-18.1)$ & $0.3(0.1-2.3)$ \\
Day 60 & $p$ value & 0.95 & 0.47 \\
& ATG-6 & $4.9(1.9-14.9)$ & $1.1(0.3-3.3)$ \\
& ATG-10 & $4.3(0.1-26.1)$ & $0.9(0.0-10.8)$ \\
Day 90 & $p$ value & 0.46 & 0.57 \\
& ATG-6 & $4.5(1.7-11.2)$ & $1.6(0.2-3.2)$ \\
& ATG-10 & $3.8(1.0-9.5)$ & $1.2(0.2-6.2)$ \\
Day 180 & $p$ value & 0.27 & 0.34 \\
& ATG-6 & $5.2(2.8-8.7)$ & $2.0(0.9-3.9)$ \\
& ATG-10 & $4.9(0.5-7.2)$ & $1.8(0.2-4.8)$ \\
Day 360 & $p$ value & 0.54 & 0.36 \\
& ATG-6 & $5.8(3.8-15.0)$ & $2.4(0.4-5.2)$ \\
& ATG-10 & $5.4(2.0-9.6)$ & $2.2(0.9-4.7)$ \\
& $p$ value & 0.58 & 0.88 \\
\hline
\end{tabular}

The recoveries of peripheral WBC and lymphocytes are indicated by the median (minimum, maximum) absolute cell counts 


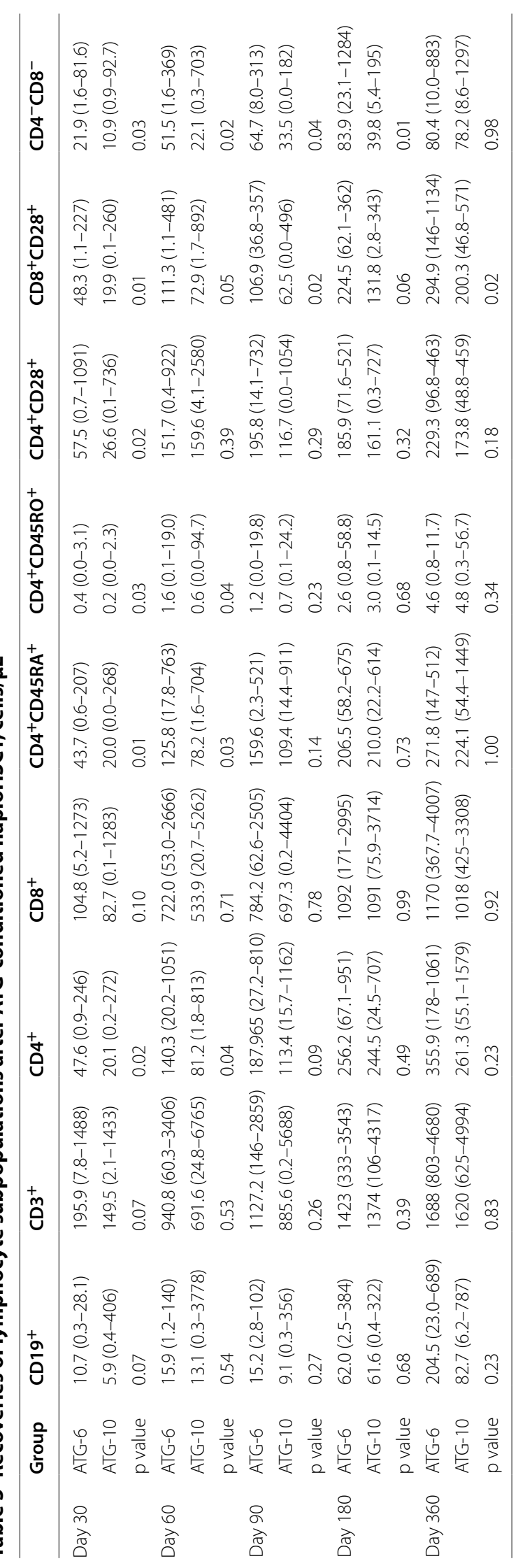


memory $\mathrm{CD} 4^{+} \mathrm{T}$ cells) in the ATG-10 group continuously declined over 60 days compared to levels in the ATG-6 group. After that, from 90 to 360 days after transplantation, the median counts of these three T-cell subsets were comparable between the two groups (Table 3). This finding suggested that the recoveries of total, naive, and memory $\mathrm{CD} 4^{+} \mathrm{T}$ cells were hamperAs presented ined by the higher dose of ATG in the early stage, but not the late stage, post-haploHSCT.

In contrast, the median counts of $\mathrm{CD} 8^{+} \mathrm{CD} 28^{+} \mathrm{T}$ cells (representing normal cytotoxic $\mathrm{T}$ lymphocytes) were apparently lower at all time points in the ATG-10 group than in the ATG-6 group. The $P$ value for comparisons at $30,60,90$, and 360 days were always $\leq 0.05$; nevertheless $P$ value rose to 0.06 at 180 days (Table 3 ). This observation implied that the recovery of active $\mathrm{CD}^{+} \mathrm{T}$ cells was slowed by a higher dose of ATG for relatively long times, and this in turn, might have contributed to the outcomes of haploHSCT observed in this group.

Notably, the recovery of a special T-cell subpopulation defined as $\mathrm{CD} 4^{-} \mathrm{CD}^{-} \mathrm{T}$ cells was also hampered in the ATG-10 group at 30, 60, 90, and 180 days, with $P$ values $<0.05$ compared to the ATG- 6 group. However, the median counts of $\mathrm{CD}^{-} \mathrm{CD}^{-} \mathrm{T}$ cells were comparable between the two groups at 360 days after haploHSCT (Table 3). It was recognized that $\mathrm{CD} 4^{-} \mathrm{CD} 8^{-} \mathrm{T}$ cells represent a small subpopulation of the normal immune system. Therefore, the impact of impairing the recovery of this double-negative T-cell subset during the first half year after ATG-conditioned haploHSCT requires further investigation.

\section{High dose ATG conditioning was associated with a lower incidence of acute GVHD but increased EBV reactivation after haploHSCT}

Next, we evaluated whether different doses of ATG administration pre-transplantation might impact the incidence of acute GVHD (aGVHD). As shown in Table 4, the total incidence of aGVHD was significantly decreased in the ATG-10 group compared to the ATG- 6 group (45.2 vs $72.4 \%, P=0.03$ ), but there was no difference in the occurrence of significant and severe aGVHD (grades II-IV) between groups. The onset time of aGVHD was comparable between groups.

It was previously shown that a higher risk of viral infections was associated with the use of ATG. In the current study, the risk of cytomegalovirus (CMV) infection was similar in the ATG-10 and ATG-6 groups. However, Epstein-Barr virus (EBV) reactivation occurred more frequently in ATG-10 group than in the ATG- 6 group (32.2 vs $6.9 \%, P=0.02$ ). The onset times of CMV and EBV reactivations were not statistically different between the two ATG-dose groups (Table 4).
Table 4 Incidences of acute GVHD and CMV/EBV infections after ATG-conditioned haploHSCT

\begin{tabular}{lccc}
\hline & ATG-6 & ATG-10 & p value \\
\hline Acute GVHD, n (\%) & & & \\
Total & $21(72.4)$ & $14(45.2)$ & 0.03 \\
Grade II-IV & $11(37.9)$ & $8(25.8)$ & 0.32 \\
Grade III-IV & $4(13.8)$ & $2(6.5)$ & 0.35 \\
Median day of onset grade II-IV & $29(10-42)$ & $30(9-80)$ & 0.32 \\
$\quad$ aGVHD (range) & & & \\
CMV reactivation, n (\%) & $22(75.9)$ & $24(77.4)$ & 0.89 \\
$\begin{array}{l}\text { Median day of onset CMV reactiva- } \\
\text { tion (range) }\end{array}$ & $36(22-77)$ & $37.5(22-102)$ & 0.73 \\
EBV reactivation, n (\%) & $2(6.9)$ & $10(32.2)$ & 0.02 \\
$\begin{array}{l}\text { Median day of onset EBV reactiva- } \\
\text { tion (range) }\end{array}$ & $60.5(47-74)$ & $51(22-102)$ & 0.61 \\
\hline
\end{tabular}

Recovery of $\mathrm{CD}^{-} \mathrm{CD}^{-} \mathrm{T}$ cells was negatively correlated with EBV reactivation after $10 \mathrm{mg} / \mathrm{kg}$ ATG conditioning Given the observation that a higher ATG conditioning dose influenced both the recovery of $\mathrm{T}$ lymphocyte subpopulations and the incidence of EBV reactivation in the current study, we were interested in determining whether these two phenotypes were correlated. Accordingly, we performed a Bivariate Correlations analysis between the median counts of $\mathrm{T}$ cell subpopulations that showed significantly delayed recoveries in the ATG-10 group (Table 3) and the incidence of EBV reactivation in that group. Among five $\mathrm{T}$ lymphocyte subsets $\left(\mathrm{CD} 4^{+}\right.$, $\mathrm{CD} 4{ }^{+} \mathrm{CD} 45 \mathrm{RA}^{+}, \mathrm{CD} 4^{+} \mathrm{CD} 45 \mathrm{RO}^{+}, \mathrm{CD}^{+} \mathrm{CD} 28^{+}$, and $\mathrm{CD} 4^{-} \mathrm{CD} 8^{-} \mathrm{T}$ cells), only the recovery of $\mathrm{CD} 4^{-} \mathrm{CD} 8^{-} \mathrm{T}$ cells on day 30 was significantly correlated to the occurrence of EBV reactivation (Spearman's $r_{p}=-0.378$, $P=0.036$, Table 5). The correlation between the recovery of $\mathrm{CD} 4^{-} \mathrm{CD} 8^{-} \mathrm{T}$ cells on day 90 and EBV infection nearly reached statistical significance (Spearman's $r_{p}=-0.352$, $P=0.066$, Table 5). We note that median onset time of EBV reactivation was 51 days (range 22-102 days) after transplantation in the ATG-10 group (Table 4). Based on this observation, we speculated that, among patients that received a higher dose of ATG, the delayed recovery of $\mathrm{CD} 4^{-} \mathrm{CD} 8^{-} \mathrm{T}$ cells in the first month increased the risk of EBV infection. In turn, an EBV infection might slow down the recovery of $\mathrm{CD}^{-}{ }^{-} \mathrm{CD} 8^{-} \mathrm{T}$ cells at later stages pos-haploHSCT.

Next, we performed a correlation analysis between the recoveries of $\mathrm{T}$ cell subpopulations and the incidence of EBV reactivation for all subjects, irrespective of the ATG dose. As presented in Table 6, the recoveries of CD4 ${ }^{-} \mathrm{CD} 8^{-} \mathrm{T}$ cells on day 30 (Spearman's $\mathrm{r}_{\mathrm{p}}=-0.313$, $P=0.015$ ) and day 90 (Spearman's $r_{\mathrm{p}}=-0.318$, $P=0.019)$ were significantly correlated to the occurrence 


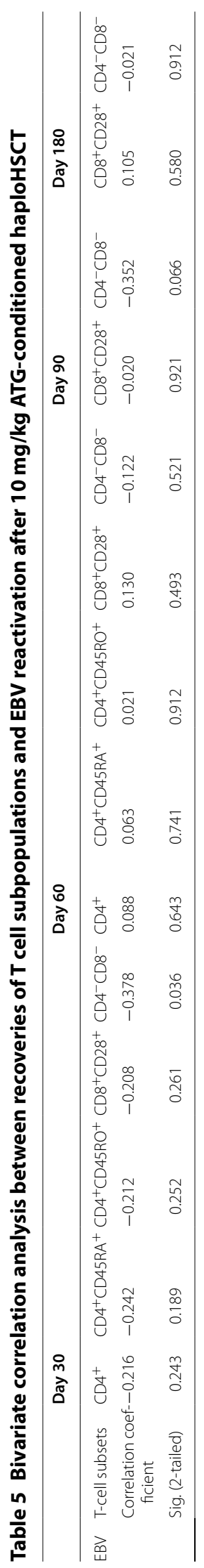




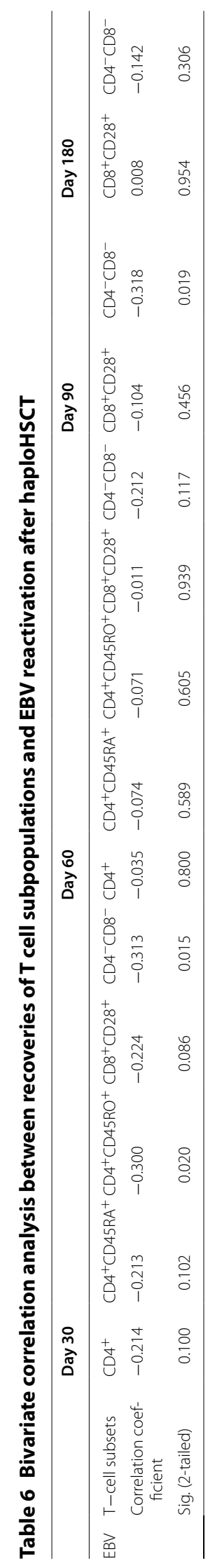


of EBV reactivation. Taken together, our data suggested that $\mathrm{CD} 4^{-} \mathrm{CD} 8^{-} \mathrm{T}$ cells could be an important subpopulation that plays a role in response to EBV infection after haploHSCT.

\section{Discussion}

T-cell depletion with ATG is a common strategy for preventing GVHD in allogeneic HSCT settings. However, the potentially negative impact of ATG has been an issue of debate [16-18]. In the setting of haploHSCT, few studies have demonstrated the influence of ATG dosage modulation on lymphocyte recovery and its association with the risk of viral infections. Consistent with our previous work [15], we showed that high-dose ATG was associated with delayed recoveries of $\mathrm{CD} 19^{+} \mathrm{B}$ cells, $\mathrm{CD}^{+} \mathrm{T}$ cells, and $\mathrm{CD} 4^{+} \mathrm{T}$ cells during the first month after haploHSCT. Here, we also showed that high-dose ATG delayed the recoveries of $\mathrm{CD} 4^{+}, \mathrm{CD} 4^{+} \mathrm{CD} 45 \mathrm{RA}^{+}$, and $\mathrm{CD} 4{ }^{+} \mathrm{CD} 45 \mathrm{RO}^{+} \mathrm{T}$ cells for 2 months, delayed the recovery of $\mathrm{CD} 4^{-} \mathrm{CD} 8^{-} \mathrm{T}$ cells for 6 months, and delayed the recovery of $\mathrm{CD} 8^{+} \mathrm{CD} 28^{+} \mathrm{T}$ cells for 12 months after transplantation. Moreover, our bivariate correlation analysis indicated that the persistent delay in $\mathrm{CD} 4^{-} \mathrm{CD} 8^{-} \mathrm{T}$ cell recovery was closely related to an increased risk of EBV infection post-haploHSCT.

Double negative, $\mathrm{CD} 4^{-} \mathrm{CD} 8^{-} \mathrm{T}$ cells are defined by exclusion; they comprise the group of $\mathrm{CD}^{+} \mathrm{T}$ cells that do not express CD4 or CD8, and they are infrequently observed in peripheral blood and lymphoid organs [19]. Traditionally, studies on double-negative $\mathrm{T}$ cells have predominantly focused on the negative effects involved in autoimmune syndromes and inflammation [20,21]. A recent review proposed potential roles of double-negative $\mathrm{T}$ cells in the normal immune system [22]. Although functional analyses of double-negative $T$ cells lagged behind analyses of well-known $\mathrm{T}$ cell subpopulations, normal double-negative $\mathrm{T}$ cells have emerged as potent effector cells involved in host defense [23]. A previous study demonstrated that double-negative $\mathrm{T}$ cells comprised a major host-response $T$ cell subset in the lungs of mice during inhalational Francisella infections [24]. In the context of HSCT, the characteristics of double-negative $\mathrm{T}$-cell recovery have not been documented. The present study was the first to report that high-dose ATG conditioning significantly delayed the recovery of $\mathrm{CD} 4^{-} \mathrm{CD} 8^{-}$ $\mathrm{T}$ cells after haploHSCT, and this delay was correlated with an increased risk of EBV reactivation. These novel findings suggested that $\mathrm{CD} 4^{-} \mathrm{CD} 8^{-} \mathrm{T}$ cells are important in protecting against viral infections; however, we could not rule out the contributions of other functional $\mathrm{T}$ cell subpopulations. In addition, $\mathrm{CD} 4^{-} \mathrm{CD} 8^{-} \mathrm{T}$ cells comprise a mixed subset which includes cells that express either $\alpha \beta$ or $\gamma \delta$ T cell receptors and, other cells that are incompletely characterized [19]. It would be interesting to identify which subset of $\mathrm{CD} 4^{-} \mathrm{CD} 8^{-} \mathrm{T}$ cells functions in protecting against EBV reactivation after HSCT.

Apart from EBV and CMV, other viruses, like adenovirus (AdV), BK virus (BKV), and human herpes virus 6 (HHV6), can potentially cause severe infections after allogeneic HSCT [25-27]. These three viruses were recently added into the list of viruses that require monitoring in routine examinations for recipients of haploHSCT in our institute. The question of whether the incidences of AdV, BKV, and HHV6 reactivation are affected by different conditioning doses of ATG awaits future investigations.

We previously reported that administration of $10 \mathrm{mg} /$ $\mathrm{kg}$ ATG resulted in a significant decrease in the occurrence of severe aGVHD compared to a $6 \mathrm{mg} / \mathrm{kg}$ ATG dose [15]. In the current study, the incidences of grades III-IV aGVHD were not statistically different between the groups, although the ratios of incidences in the ATG10 versus ATG-6 group were $6.5 \%(2 / 31)$ and $13.8 \%$ (4/29; Table 4). The failure to observe a difference could be attributed to the limited size of the present retrospective study.

Both the dosage and timing of ATG administration have been suggested as critical factors in T-lymphocyte recovery after HSCT [9]. The present study showed that $6 \mathrm{mg} / \mathrm{kg}$ ATG was related to a faster recovery of T cell subsets and lower incidence of EBV infection after haploHSCT, compared to $10 \mathrm{mg} / \mathrm{kg}$ AGT. Our previous study showed a significant reduction in the occurrence of severe aGVHD with $10 \mathrm{mg} / \mathrm{kg}$ ATG treatment. Because the overall survival rates were comparable between the ATG-6 and ATG-10 groups [15], we currently use $10 \mathrm{mg}$ / kg ATG to reduce the occurrence of aGVHD. Further investigation is required to determine whether an intermediate ATG dose might preserve the protective effect of preventing GVHD without delaying T-cell recovery. We recently initiated a multi-center clinical trial to compare the outcomes of recipients of haploHSCT that received 10 versus $7.5 \mathrm{mg} / \mathrm{kg}$ ATG. We hope the results of that trial will facilitate optimization of the ATG conditioning dose. On the other hand, it has been shown that conditioning with ATG closer to the day of transplantation and longer active ATG exposure were correlated with slower T-cell recovery after HSCT $[28,29]$. In the present study, blood concentrations of active ATG after haploHSCT were not monitored. However, evaluation of the time of lymphocyte exposure to ATG and its impact on T-cell reconstitution may also facilitate optimization of the conditioning dosage and timing pre-haploHSCT.

\section{Conclusions}

The present study demonstrated that $10 \mathrm{mg} / \mathrm{kg}$ ATG, compared to $6 \mathrm{mg} / \mathrm{kg}$ ATG, significantly hampered 
the recoveries of some T-cell subpopulations in a timedependent manner, post-haploHSCT. Our study was the first to connect the recovery of $\mathrm{CD} 4^{-} \mathrm{CD} 8^{-} \mathrm{T}$ cells to the risk of EBV infection after HSCT. Future prospective and large cohort studies should provide more unbiased evidences to clarify our findings and benefit the overall outcome in recipients of haploHSCT.

\section{Authors' contributions}

$J \mathrm{~L}$ collected and analyzed the data, and wrote the manuscript. LPX, ZB, YJC, YW, and XHZ collected and interpreted the data; XJH designed the study and critically revised the manuscript. All authors read and approved the final manuscript.

\section{Acknowledgments}

This study is supported by Key Program of the National Natural Science Foundation of China (Grant no. 81230013) and National Natural Science Foundation of China (Grant no. 81370666).

\section{Competing interests}

The authors declare that they have no competing interests.

Received: 6 August 2015 Accepted: 4 December 2015

Published online: 30 December 2015

\section{References}

1. Theurich S, Fischmann H, Chakupurakal G, Shimabukuro-Vornhagen A, Chemnitz JM, Holtick U, Rothe A, Scheid C, Hallek M, Skoetz N, von Bergwelt-Baildon M. Anti-thymocyte globulins for post-transplant graftversus-host disease prophylaxis-A systematic review and meta-analysis. Crit Rev Oncol Hematol. 2013;88:178-86.

2. Devillier R, Furst S, El-Cheikh J, Castagna L, Harbi S, Granata A, Crocchiolo R, Oudin C, Mohty B, Bouabdallah R, et al. Antithymocyte globulin in reduced-intensity conditioning regimen allows a high disease-free survival exempt of long-term chronic graft-versus-host disease. Biol Blood Marrow Transplant. 2014;20:370-4.

3. Dulery R, Mohty M, Duhamel A, Robin M, Beguin Y, Michallet M, Vigouroux S, Lioure B, Garnier A, El Cheikh J, et al. Antithymocyte globulin before allogeneic stem cell transplantation for progressive myelodysplastic syndrome: a study from the French Society of Bone Marrow Transplantation and Cellular Therapy. Biol Blood Marrow Transplant. 2014;20:646-54

4. Kroger N, Zabelina T, Binder T, Ayuk F, Bacher U, Amtsfeld G, Lellek H, Schrum J, Erttmann R, Eiermann T, Zander A. HLA-mismatched unrelated donors as an alternative graft source for allogeneic stem cell transplantation after antithymocyte globulin-containing conditioning regimen. Biol Blood Marrow Transplant. 2009;15:454-62.

5. Huang XJ, Liu DH, Liu KY, Xu LP, Chen H, Han W, Chen YH, Zhang XH, Lu DP. Treatment of acute leukemia with unmanipulated HLA-mismatched/ haploidentical blood and bone marrow transplantation. Biol Blood Marrow Transplant. 2009;15:257-65.

6. Huang XJ, Liu DH, Liu KY, Xu LP, Chen H, Han W, Chen YH, Wang JZ, Gao ZY, Zhang YC, et al. Haploidentical hematopoietic stem cell transplantation without in vitro T-cell depletion for the treatment of hematological malignancies. Bone Marrow Transplant. 2006;38:291-7.

7. Finke J, Schmoor C, Lang H, Potthoff K, Bertz H. Matched and mismatched allogeneic stem-cell transplantation from unrelated donors using combined graft-versus-host disease prophylaxis including rabbit anti-T lymphocyte globulin. J Clin Oncol. 2003;21:506-13.

8. Mohty M. Mechanisms of action of antithymocyte globulin: T-cell depletion and beyond. Leukemia. 2007;21:1387-94.

9. Bacigalupo A. Antithymocyte globulin in the conditioning regimen: why not? Biol Blood Marrow Transplant. 2014;20:597-8.

10. Finke J, Bethge WA, Schmoor C, Ottinger HD, Stelljes M, Zander AR, Volin L, Ruutu T, Heim DA, Schwerdtfeger R, et al. Standard graftversus-host disease prophylaxis with or without anti-T-cell globulin in haematopoietic cell transplantation from matched unrelated donors: a randomised, open-label, multicentre phase 3 trial. Lancet Oncol. 2009;10:855-64.

11. Bacigalupo A, Lamparelli T, Bruzzi P, Guidi S, Alessandrino PE, di Bartolomeo P, Oneto R, Bruno B, Barbanti M, Sacchi N, et al. Antithymocyte globulin for graft-versus-host disease prophylaxis in transplants from unrelated donors: 2 randomized studies from Gruppo Italiano Trapianti Midollo Osseo (GITMO). Blood. 2001;98:2942-7.

12. Veys P, Wynn RF, Ahn KW, Samarasinghe S, He W, Bonney D, Craddock J, Cornish J, Davies SM, Dvorak CC, et al. Impact of immune modulation with in vivo T-cell depletion and myleoablative total body irradiation conditioning on outcomes after unrelated donor transplantation for childhood acute lymphoblastic leukemia. Blood. 2012;1 19:6155-61.

13. Bosch M, Khan FM, Storek J. Immune reconstitution after hematopoietic cell transplantation. Curr Opin Hematol. 2012;19:324-35.

14. Na IK, Wittenbecher F, Dziubianau M, Herholz A, Mensen A, Kunkel D, Blau O, Blau I, Thiel E, Uharek L, et al. Rabbit antithymocyte globulin (thymoglobulin) impairs the thymic output of both conventional and regulatory CD4+ T cells after allogeneic hematopoietic stem cell transplantation in adult patients. Haematologica. 2013;98:23-30.

15. Wang Y, Fu HX, Liu DH, Xu LP, Zhang XH, Chang YJ, Chen YH, Wang FR, Sun $Y Q$, Tang FF, et al. Influence of two different doses of antithymocyte globulin in patients with standard-risk disease following haploidentical transplantation: a randomized trial. Bone Marrow Transplant. 2014;49:426-33

16. Bosch M, Dhadda M, Hoegh-Petersen M, Liu Y, Hagel LM, Podgorny P, Ugarte-Torres A, Khan FM, Luider J, Auer-Grzesiak I, et al. Immune reconstitution after anti-thymocyte globulin-conditioned hematopoietic cell transplantation. Cytotherapy. 2012;14:1258-75.

17. Soiffer RJ, Lerademacher J, Ho V, Kan F, Artz A, Champlin RE, Devine S, Isola L, Lazarus HM, Marks DI, et al. Impact of immune modulation with anti-T-cell antibodies on the outcome of reduced-intensity allogeneic hematopoietic stem cell transplantation for hematologic malignancies. Blood. 2011;117:6963-70.

18. Schmidt-Hieber M, Schwarck S, Stroux A, Ganepola S, Reinke P, Thiel E, Uharek L, Blau IW. Immune reconstitution and cytomegalovirus infection after allogeneic stem cell transplantation: the important impact of in vivo T cell depletion. Int J Hematol. 2010;91:877-85.

19. Hillhouse EE, Lesage S. A comprehensive review of the phenotype and function of antigen-specific immunoregulatory double negative T cells. J Autoimmun. 2013;40:58-65.

20. Juvet SC, Zhang L. Double negative regulatory T cells in transplantation and autoimmunity: recent progress and future directions. J Mol Cell Biol. 2012;4:48-58.

21. Crispin JC, Tsokos GC. Human TCR-alpha beta+ CD4- CD8- T cells can derive from $C D 8+T$ cells and display an inflammatory effector phenotype. J Immunol. 2009;183:4675-81.

22. Martina MN, Noel S, Saxena A, Rabb H, Hamad AR. Double negative (DN) alphabeta T cells: misperception and overdue recognition. Immunol Cell Biol. 2015;93:305-10.

23. D'Acquisto F, Crompton T. CD3 + CD4- CD8 - (double negative) T cells: saviours or villains of the immune response? Biochem Pharmacol. 2011;82:333-40

24. Cowley SC, Meierovics Al, Frelinger JA, Iwakura Y, Elkins KL. Lung CD4_ CD8- double-negative T cells are prominent producers of IL-17A and IFN-gamma during primary respiratory murine infection with Francisella tularensis live vaccine strain. J Immunol. 2010;184:5791-801.

25. Chakrabarti S, Mautner V, Osman H, Collingham KE, Fegan CD, Klapper $P E$, Moss PA, Milligan DW. Adenovirus infections following allogeneic stem cell transplantation: incidence and outcome in relation to graft manipulation, immunosuppression, and immune recovery. Blood. 2002;100:1619-27.

26. Gratwohl A, Brand R, Frassoni F, Rocha V, Niederwieser D, Reusser P, Einsele H, Cordonnier C, Acute, Chronic Leukemia Working P. Cause of death after allogeneic haematopoietic stem cell transplantation (HSCT) in early leukaemias: an EBMT analysis of lethal infectious complications and changes over calendar time. Bone Marrow Transplant. 2005;36:757-69.

27. Wang $L R$, Dong $L$, Zhang $M J$, Lu DP. The impact of human herpesvirus $6 B$ reactivation on early complications following allogeneic hematopoietic stem cell transplantation. Biol Blood Marrow Transplant. 2006;12:1031-7. 
28. Willemsen $L$, Jol-van der Zijde CM, Admiraal R, Putter $H$, JansenHoogendijk AM, Ostaijen-Ten Dam MM, Wijnen JT, Van Kesteren C, Waaijer $J$, Lankester AC, et al. Impact of serotherapy on immune reconstitution and survival outcomes after stem cell transplantations in children: thymoglobulin versus alemtuzumab. Biol Blood Marrow Transplant. 2015;21:473-82.
29. Lindemans CA, Chiesa R, Amrolia PJ, Rao K, Nikolajeva O, de Wildt A, Gerhardt CE, Gilmour KC, Bierings M, Veys P, Boelens JJ. Impact of thymoglobulin prior to pediatric unrelated umbilical cord blood transplantation on immune reconstitution and clinical outcome. Blood. 2014;123:126-32.
Submit your next manuscript to BioMed Central and we will help you at every step:

- We accept pre-submission inquiries

- Our selector tool helps you to find the most relevant journal

- We provide round the clock customer support

- Convenient online submission

- Thorough peer review

- Inclusion in PubMed and all major indexing services

- Maximum visibility for your research

Submit your manuscript at www.biomedcentral.com/submit
(OioMed Central 